\title{
Uncertainty and International Capital Flows
}

\author{
François Gourio Michael Siemer Adrien Verdelhan*
}

December 22, 2014

Preliminary and Incomplete

\begin{abstract}
In a large panel of 26 emerging countries over the last 40 years, aggregate stock market return volatilities, our measure of uncertainty, forecast capital flows. When the stock market return volatility increases, capital inflows decrease and capital outflows increase. We propose a simple decomposition of each country's market return volatility into two components: countries differ by their exposure to systematic volatility, measured by their uncertainty betas, and by their country-specific volatility. Capital inflows respond to both systematic and countryspecific shocks to volatility, and they respond more in high uncertainty beta countries. These results are all statistically significant. A simple portfolio choice model illustrates the impact of uncertainty on gross capital flows: in the model, foreigners are exposed to expropriation risk. When the probability of expropriation increases, foreigners sell the domestic assets to the domestic investors, leading to a counter-cyclical home bias.
\end{abstract}

JEL: E32, E44, G12, F32.

${ }^{*}$ Gourio: Federal Reserve Bank of Chicago and NBER. Address: 230 South LaSalle St, Chicago IL 60604; francois.gourio@chi.frb.org; phone: (312) 322-5627; http://sites.google.com/site/fgourio/. Siemer: Board of Governors of the Federal Reserve System. Address: Division of Research and Statistics, Macroeconomic and Quantitative Studies, 20th \& Constitution Ave NW, Washington DC 20551; michael.siemer@frb.gov; phone: (202) 912-7860; personal website: http://www.michael-siemer.com. Verdelhan: MIT Sloan and NBER. Address: Department of Finance, MIT Sloan School of Management, E62-621, 77 Massachusetts Avenue, Cambridge, MA 02139; adrienv@mit.edu; phone: (617) 253-5123; http://web.mit.edu/adrienv/www/. The views expressed here are those of the authors and do not necessarily represent those of the Federal Reserve Bank of Chicago, the Federal Reserve Board, or the Federal Reserve System. The authors thank Gita Gopinath, Pierre-Olivier Gourinchas, Matteo Maggiori, Fabrizio Perri, and seminar participants at the NBER Universities' Research Conference on "The Macroeconomic Consequences of Risk and Uncertainty" and at the Chicago Booth International Macro Finance Conference for helpful comments and suggestions. Victor Duarte provided outstanding research assistance. 


\section{Introduction}

International capital flows among emerging economies increased dramatically in the last 25 years. But in 2008, at a time of great global uncertainty, international capital inflows and outflows collapsed. In this paper, we study, both empirically and theoretically, the response of international capital flows to global uncertainty shocks. In a large panel of emerging countries over the last 40 years, we find that the amount of uncertainty predicts future capital flows. We provide a model, featuring expropriation risk, to interpret the data.

We measure uncertainty in each country using the realized aggregate stock market volatility in that country. This measure is simple and available in real time. The impact on capital flows is unambiguous: volatility increases lead to "retrenchment." Future capital inflows and net inflows decrease and capital outflows increase when total volatility increases. The effects are statistically significant and robust to many controls, including country and time fixed effects.

This result is driven by both global and local shocks. To disentangle the two, we regress the realized volatility of a country's stock market return on the world stock market volatility, over rolling windows. The slope coefficients in these regressions are our uncertainty betas. Total volatility can therefore be decomposed into a systematic and a country-specific component. Differences in exposure to systematic volatility are driven by differences in uncertainty betas.

We find that capital outflows, inflows, and net inflows respond significantly to country-specific volatility shocks. Future capital inflows and net inflows decrease and capital outflows increase when country-specific volatility increases. In other words, when country-specific volatility rises, foreigners pull their capital out of the high beta countries and the domestic residents of those same high beta countries sell more foreign assets than they buy. But global shocks to volatility matter too, and they matter more for high uncertainty beta countries. Capital inflows and net inflows decrease significantly more in high uncertainty beta countries than in low uncertainty beta countries in response to a global uncertainty shock. In our dataset, past uncertainty betas therefore predict the impact of future uncertainty shocks. Because volatilities and their subcomponents are estimated over rolling windows that do not encompass each global uncertainty shock under study, 
there is no mechanical look-ahead bias in our results.

The same volatility shocks affect macroeconomic variables: consistent with the literature on the impact of aggregate uncertainty, when total volatility increases, consumption, investment, GDP, industrial production, and employment tend to fall. Here again the effects are statistically significant and robust to many controls, including country and time fixed effects. Asset markets, which are inherently forward-looking, contain information about future capital flows and real economic activity, as well as about future differences across countries.

Capital flows depend naturally on investors' decision to invest abroad. According to a World Bank's survey (World Investment and Political Risk, 2013), the two major constraints to foreign investment are political risk and macroeconomics instability. Our empirical finding speak to these concerns. Stock market return volatility is of course very often related to macroeconomics instability, and a high expected return volatility makes investment in a risky asset less attractive in any classic optimal portfolio problem. But an increase in expected volatility affects domestic and foreign investors in the same way, and cannot per se account for the capital reallocation between foreign and domestic investors that we see in the data. In this paper, we therefore focus on political risk, more precisely on expropriation risk, the component of political risk that is the most directly relevant to foreign investors.

Expropriation risk is a major concern for foreign investors in emerging markets. A large market of political risk insurance, many legal disputes, and many political risk indices confirm the prevalence of this concern. The Berne Union, an association of public, private, and multilateral insurance providers, reports statistics on the political risk insurance market. Political risk insurance represented up to $25 \%$ of foreign direct investment for developing economies in 1982 . It is down to 14 percent of foreign direct investment, but still accounts for $\$ 100$ billion of investment insurance issued in 2012. The Multilateral Investment Guarantee Agency (World Bank Group) offers standardized insurance contracts against the expropriation risk inherent in both foreign direct investments and portfolio investments. Legal fights about expropriation cases are common, and a mechanism exists to settle these fights: the International Centre for Settlement of Investment 
Disputes is the leading international arbitration institution devoted to resolving disputes between States and foreign investors. Several firms produce and sell country risk indices to potential investors. The IHS Group, for example, builds quarterly indices of country risk. The first component of each country index corresponds to the likelihood of a 10-percentage-point increase in the rate of capital gains tax for foreign-owned businesses. The International Country Risk Guide (ICRG) is another large database of political risk indices available at the annual frequency but over a long time window and for a large cross-section of countries. Expropriation risk is an actual, multi-form, and major source of risk for investors in emerging markets.

In the data, we proxy expropriation by a measure of capital account openness, based on the IMF annual reports, and the ICRG political risk index. Both capital account openness and political risk indices appear significantly correlated with the stock market return volatility. Times of high market volatility are times of larger capital controls and higher political risk. We therefore propose an interpretation of the dynamics of the gross capital flows based on time-variation in expropriation risk.

Our model translates the general concern for expropriation risk in a simple form. The model is an international portfolio problem in incomplete markets. In the two-country setting, each country has a representative investor and a tree producing dividends. Investors can invest in both the domestic and foreign trees. But a key friction breaks the symmetry between investors. We assume that the foreign investor is exposed to the risk of expropriation when investing in the home tree, whereas home investors are not. Expropriation risk acts like a tax on foreign holdings of the home tree. The tax is a low-probability event, and its magnitude increases with the foreign holdings, as governments are likely to face higher incentives to expropriate foreigners when foreign holdings are sizable.

In the model, dividends and the probability of expropriation follow persistent processes but, for the sake of the exposure, they respond to different and uncorrelated shocks. Because of the key role of non-linearities, we cannot rely on log-linearizations and therefore compute the model equilibrium using projection methods. To study the model dynamics, let us consider an temporary 
increase in the expropriation probability. The foreign agent, faced with a higher probability of expropriation next period, sells some of her holdings of the domestic tree to the domestic agent, who is immune to the risk of expropriation. As a result, capital first flows out of the domestic economy. The price of the domestic tree decreases because of its higher risk. As the expropriation probability reverts to its mean, the foreign agent increases its holdings of the domestic tree, but at a lower price than in equilibrium. As a result, capital flows again towards the domestic economy, but the inflows are smaller than the previous outflows.

The model provides a potential, but clearly not the unique, explanation to the dynamics of gross capital flows. In the logic of the model, the initial shock is the increase in political risk; it implies more volatile asset prices and gross capital flows out of the country. In the real world, the increase in political risk is certainly correlated with the state of the economy. Thus news about future real activity or future expropriation may trigger capital flights. The model could be easily extended to speak to the differences across countries by introducing a global component in the endowment processes and in the expropriation probabilities. Even without such systematic component, comparative statics already show that the sensitivity of the tax rate to the foreign holdings govern the size of the price and capital flows responses: the larger the expropriation risk, the larger the stock price changes, and the larger the capital flows leaving the riskier country.

Our paper is related to different strands of the literature, on closed as well as on open economies. Focusing on closed economies, a recent and fast-growing literature investigates the impact of uncertainty shocks, following the seminal work of Bloom (2009). Bloom (2013) presents an exhaustive review of this literature. We review the most recent work in a literature section in the Online Appendix.

Focusing on open economies, a recent literature shows that gross outflows and inflows are more informative than net flows. ${ }^{1}$ Our work builds on two key findings in this literature: the link between capital flows and country crises, and the link between capital flows and measures of U.S.

\footnotetext{
${ }^{1}$ See Gourinchas and Rey (2007a, 2007b) Lane and Milesi-Ferretti (2007), Backus, Henriksen, Lambert and Telmer (2009), Fratzscher (2012), Obstfeld (2012a, 2012b), Forbes and Warnock (2012), Gourinchas, Rey and Truempler (2012), Rey (2013), and Broner et al. (2013). Rey (2013) shows that gross outflow and inflows are highly correlated across countries, while net flows are not. Miranda-Agrippino and Rey (2014) study the link between capital flows and U.S. monetary policy.
} 
volatility. Broner et al. (2013) analyze the behavior of gross capital flows over the business cycle and during financial crises. Instead of taking the dates of financial crises from the literature, we explore the predictive content of market return volatility. Rey (2013) shows that gross capital flows respond contemporaneously to changes in the VIX, the U.S. option-implied volatility index, over the post-1990 sample. Forbes and Warnock (2012) obtain a similar result by focusing on large capital inflows and outflows and using the VXO index, the ancestor of the VIX, over the post-1986 period, as well as other risk factors. Bruno and Shin (2014) and Cerutti et al. (2014) report similar results on bank flows. We extend the analysis to emerging market volatilities over the 1970-2011 sample, decompose these volatilities into their country-specific and systematic components, and study their predictive content. We add a key, ex ante source of heterogeneity across countries, i.e., their exposure to global uncertainty shocks.

Our empirical work extends Gourio, Siemer and Verdelhan (2013) and Carrière-Swallow and Céspedes (2013) by considering the impact of global volatility shocks on capital flows and relates naturally to the sudden stop literature. ${ }^{2}$ Our sample encompasses all the sudden stop episodes identified in this literature over the last 40 years. Our uncertainty measures offer additional country characteristics to assess the likelihood of a sudden stop.

Our model is part of a recent set of general equilibrium models of international portfolio allocations, notably Caballero, Farhi and Gourinchas (2008), Mendoza, Quadrini and Rios-Rull (2009), Coeurdacier, Rey, and Winant (2011, 2013), Gourinchas, Rey, and Govillot (2010), Coeurdacier and Gourinchas (2011), Colacito and Croce (2010, 2011), Tille and van Wincoop (2012), Devereux and Sutherland (2012), Maggiori (2012), Bahmra, Coeurdacier, and Guibaud (2013), Chang, Kim and Lee (2013), Colacito et al. (2013), Gabaix and Maggiori (2013), Heathcote and Perri (2013), Kalemli-Ozcan, Papaioannou and Perri (2013), Caballero and Farhi (2014), Fornaro (2014), and Kollmann (2015). We focus on one key, novel friction, but our model could naturally be extended by adding more assets and more frictions, building on this recent literature.

\footnotetext{
${ }^{2}$ Key contributions in this literature include Calvo (1998), Edwards (2002, 2004), Kim and Wei (2002), Choe, Kho and Stulz (2005), Calvo, Izquierdo and Talvi (2006a, 2006b), Fogli and Perri (2006), Albuquerque, Bauer and Schneider (2007), Durdu, Mendoza and Terrones (2009), Milesi-Ferretti and Tille (2011), Rothenberg and Warnock (2011), and Ahmed and Zlate (2012).
} 
The rest of the paper is organized as follows. Section 2 introduces our dataset, volatility measures, and uncertainty betas. Section 3 reports the response of capital flows and other macroeconomic variables to stock return volatility shocks. Section 4 links stock return volatility to different measures of expropriation risk. Section 5 presents a model of expropriation risk and the simulated response of capital flows to increases in the probability of expropriation. Section 6 concludes.

\section{Systematic and Country-specific Uncertainty}

This section describes the dataset and the construction of volatility measures and uncertainty betas.

\subsection{Data}

Our dataset includes the following 26 developing countries: Argentina, Brazil, Bulgaria, Chile, Colombia, Czech Republic, Egypt, Hungary, India, Indonesia, Israel, Malaysia, Mexico, Morocco, Peru, Philippines, Poland, Portugal, Romania, Singapore, Slovenia, South Africa, South Korea, Taiwan, Thailand, and Turkey. The sample extends from January 1970 to March 2011 but some series start later than others. We briefly describe the data sources, starting with the macroeconomic variables before turning to asset prices.

Macroeconomic Data Import, export, international reserves, industrial production, consumer prices, and unemployment rate series are from the International Monetary Fund's (IMF) International Financial Statistics (IFS). The series are monthly. Consumption, investment, and GDP are also from the IFS database; those series are quarterly.

Capital flows are measured at the quarterly frequency, over the 1970-2011 sample. All series are scaled by GDP and de-seasonalized using the X-12-Arima seasonal adjustment procedure. Net international capital flows can be approximated by the amount of net exports, but the financial accounts of the balance of payments offer a more precise description of gross international capital flows. The balances of payments distinguish between foreign direct investment, portfolio flows, 
and the remainder, denoted "other flows" (which include notably bank flows). Gross international capital flows are compiled by Bluedorn, Duttagupta, Guajardo and Topalova (2013) from the IMF balances of payments (version 5), supplemented with other IMF and country sources. Gross outflows and gross inflows are actually net items following standard balance of payments accounting. Gross outflows are defined as net purchases of foreign financial instruments by domestic residents. Gross inflows are defined as net sales of domestic financial instruments to foreign residents. Net capital flows are defined as the difference between gross outflows and gross inflows. ${ }^{3}$

Financial Data Nominal exchange rates, expressed in foreign currency per U.S. dollar, and nominal short term interest rates are also from the IFS database. We use Treasury bill rates whenever available, and money market rates otherwise. Real interest rates are obtained as the nominal interest rates minus expected inflation rates, measured as the last 12-month differences in $\log$ consumer price indices.

Weekly stock market indices, denoted $R^{m}$, are from the Morgan Stanley Country Indices (MSCI), Datastream, and Global Financial Data (GFD) stock market databases. Long time series of aggregate stock returns for Argentina, Brazil, Chile, Colombia, Ecuador, Indonesia, Malaysia, Mexico, Morocco, Nigeria, Peru, Russia, South Africa, South Korea, Thailand, Turkey and Uruguay are from the GFD database. Weekly real stock market returns are obtained by subtracting weekly inflation rates to the nominal stock returns. Weekly price indices are obtained by linear interpolation of monthly price indices. Our stock market return indices are expressed in local currency, but we obtain similar results with returns in U.S. dollars. Stock market return volatilities offer a simple, robust, and timely measure of uncertainty.

\footnotetext{
${ }^{3}$ By convention, positive outflows mean that residents are selling more foreign assets than they are buying, contributing positively to net inflows. Intuitively, a positive outflow means than money is leaving the foreign country and coming to the home country. In the U.S., outside crisis episodes, outflows tend to be negative: money is leaving the U.S. to be invested in foreign countries. Positive inflows means that foreigners are purchasing more domestic assets than they are selling, contributing positively to net inflows. Intuitively, a positive inflow is means that money is flowing into the home country.
} 


\section{$2.2 \quad$ Volatilities}

We first present a simple framework to think about time-varying volatility and then describe precisely how we measure volatilities in the data and decompose them into country-specific and global components.

Stock Market Heteroscedasticity Let us assume that the aggregate stock return in country $i$ is driven by some world $\left(u_{t+1}^{w}\right)$ and country $i$-specific $\left(u_{t+1}^{i}\right)$ shocks:

$$
R_{t+1}^{i}=\alpha_{R}^{i}+\sqrt{\chi^{i}} \sqrt{z_{t}^{w}} u_{t+1}^{w}+\sqrt{\delta^{i} z_{t}^{w}+\gamma^{i} z_{t}^{i}} u_{t+1}^{i}
$$

The world shocks are, for example, summarized by the world stock market returns, and denoted here by $\sqrt{z_{t}^{w}} u_{t+1}^{w}$. In the logic of the Capital Asset Pricing Model (CAPM), the world stock market returns measure aggregate, systematic risk. The parameter $\sqrt{\chi^{i}}$ denotes the CAPM loading on aggregate returns. Since all the shocks are i.i.d. and gaussian, the country-specific $\left(z_{t}^{i}\right)$ and world $\left(z_{t}^{w}\right)$ state variables govern the time-varying volatilities of stock market returns. The volatility of the world shocks is $z_{t}^{w}$, while the volatility of the idiosyncratic part of the returns is $\delta^{i} z_{t}^{w}+\gamma^{i} z_{t}^{i}$. The state variables follow autoregressive square root processes so that they remain positive:

$$
\begin{aligned}
& z_{t+1}^{i}=(1-\phi) \theta+\phi z_{t}^{i}-\sigma \sqrt{z_{t}^{i}} \varepsilon_{t+1}^{i} \\
& z_{t+1}^{w}=\left(1-\phi^{w}\right) \theta^{w}+\phi^{w} z_{t}^{w}-\sigma^{w} \sqrt{z_{t}^{w}} \varepsilon_{t+1}^{w} .
\end{aligned}
$$

where the country $i$-specific and global shocks $\varepsilon_{t+1}^{i}$ and $\varepsilon_{t+1}^{w}$ are also i.i.d. and gaussian. The variance of the stock return in country $i$ is:

$$
\sigma_{t}^{2}\left(R_{t+1}^{i}\right)=\left(\chi^{i}+\delta^{i}\right) z_{t}^{w}+\gamma^{i} z_{t}^{i}
$$

Total volatility has therefore two components, an aggregate component, equal to $\left(\chi^{i}+\delta^{i}\right) z_{t}^{w}$, and a country-specific volatility component, equal to $\gamma^{i} z_{t}^{i}$. We define the uncertainty beta, or 
volatility beta, by regressing country $i$ 's aggregate volatility on the volatility of the risk factor. The uncertainty beta is therefore $\beta^{i}=\chi^{i}+\delta^{i}$. Our paper is about (1) the impact of countryspecific volatility shock $\varepsilon_{t+1}^{i}$ on international capital flows and macroeoconomic quantities, and (2) the impact of a global volatility shock $\varepsilon_{t+1}^{w}$ on international capital flows, and more precisely about the differential impact across countries with different $\beta^{i}$ s. We turn now to the description of those volatility measures in the data.

Volatility Measures Total volatility at the quarterly frequency corresponds to the average of weekly squared real stock market returns over a quarter. To decompose total volatility into its aggregate and country-specific components, we regress each country $i$ squared returns on the world stock market squared returns:

$$
\left(R_{k}^{i}\right)^{2}=\alpha^{i}+\beta^{i}\left(R_{k}^{w}\right)^{2}+\xi_{k}^{i}
$$

where $R_{k}^{i}$ is the return on country $i$ during week $k, R_{k}^{w}$ is the return on the world stock market index during week $k$. The regression is run over one year of data to provide sufficient power to estimate the betas. We therefore define three volatility components in the data:

$$
\begin{aligned}
\text { Total volatility } & : \frac{1}{\tau_{2}+1} \sum_{k=t^{*}-\tau_{2}}^{t^{*}}\left(R_{k}^{i}\right)^{2} \\
\text { Country-specific volatility } & : \frac{1}{\tau_{2}+1} \sum_{k=t^{*}-\tau_{2}}^{t^{*}}\left(\alpha^{i}+\xi_{k}^{i}\right) \\
\text { Global component of volatility } & : \frac{1}{\tau_{2}+1} \sum_{k=t^{*}-\tau_{2}}^{t^{*}} \beta_{i}\left(R_{k}^{w}\right)^{2}
\end{aligned}
$$

where $t^{*}$ denotes the last week of each quarter and $\tau_{2}$ is one quarter to match the frequency of the capital flows and macro variables. By construction, total volatility is the sum of the countryspecific and global volatilities. The decomposition and the uncertainty betas are time-varying since the regressions are estimated on rolling windows. We use these volatility measures as proxy for total, country-specific, and systematic uncertainty. 


\section{The Response of Capital Flows and Economic Activity to Volatility Shocks}

This section reports the response of capital flows and other macroeconomic variables to volatility shocks. We run quarterly panel regressions of capital flows (or other macroeconomic variables) on past volatility:

$$
C F_{t}^{i}=\alpha_{i}+\beta_{1} V o l_{t-1}^{i}+\beta_{2} * C F_{t-1}^{i}+\beta_{3} * C F_{t-2}^{i}+\beta_{4} R_{t-1}^{i}+\beta_{5} * \Delta y_{t-1}^{i}+\beta_{6} \Delta y_{t-2}^{i}+\varepsilon_{t}^{i}
$$

where $C F$ denotes capital outflows, inflows or net inflows. We run similar tests for other macroeconomic variables (e.g., GDP, consumption, investment). All regressions include country fixed effects, controls (lagged market return $R_{t-1}^{i}$ and two lags of GDP growth, $\Delta y_{t-1}^{i}, \Delta y_{t-2}^{i}$ ), and lagged values of the dependent variable. The standard errors are clustered by time and country, following Petersen (2009) and Cameron, Gelbach and Miller (2011).

\subsection{Capital Flows}

Table 1 reports regression results obtained on capital flows. Increases in total volatility decrease significantly net inflows in emerging countries, approximated by the opposite of net exports or measured in the balances of payments. ${ }^{4}$ Increases in total volatility decrease capital inflows and increase capital outflows, both significantly. Total volatility shocks therefore entail some "retrenchment": foreign ressources flow less into the country, and domestic investors invest less abroad. Are capital flows responding to local or global uncertainty shocks? To answer this question, we turn now to the two components of volatility.

The country-specific component of return volatility again decreases significantly net inflows, lowering inflows and increasing outflows. The global component of volatility impacts significantly

\footnotetext{
${ }^{4}$ The trade balance measure does not correspond exactly to the inverse of net capital inflows for a variety of reasons. First, we only measure trade in goods and not trade in services. Second, the income of foreign factors of production and unilateral transfers are missing. Last, the current account and the financial account do not match perfectly. In our data, the correlation between the two series is -0.62 .
} 
the capital inflows to emerging countries: when global volatility increases, inflows to emerging countries dry up. Global shocks to volatility do not seem to affect significantly outflows from emerging countries.

The global component of volatility summarizes two effects: the global volatility that affects all countries and the country-specific exposure - the uncertainty beta - to global volatility. In order to control for the former and focus on the latter, we add time fixed effects to the panel regression. The time fixed effects capture all global shocks; therefore only differences in uncertainty beta can impact capital flows. They do so significantly for inflows and net inflows, but not for outflows. Countries that have high uncertainty betas experience lower inflows when global volatility rises. Foreigners pull their capital out of the most risky countries in times of crises. This result is driven mostly by private capital flows (official transactions are not important) and in particular by the "other inflows." High uncertainty beta countries experience significantly lower net inflows in times of global volatility shocks.

In a nutshell, capital inflows decrease and capital outflows increase when total volatility increases. Capital outflows, inflows and net inflows respond to country-specific volatility shocks. Capital inflows and net inflows decrease more in high uncertainty beta countries than in low uncertainty beta countries in response to a global uncertainty shock. All these effects are statistically significant.

\subsection{Real Economic Activity}

Let us turn now to the impact of volatility shocks on real economic activity. Table 2 reports regression results obtained GDP, investment, consumption, industrial production, and (the opposite of) the unemployment rate. All responses are statistically significant and in the same direction: an increase in total volatility decreases real economic activity. GDP, investment, consumption, industrial production, and employment all decline in response to an uncertainty shock. This result is consistent with the literature on the impact of uncertainty. Only country-specific volatility shocks though affect significantly these macroeconomic variables. The negative impact of country-specific 
Table 1: Capital Flows and Volatility Shocks

\begin{tabular}{lcccc}
\hline \hline & NX/GDP & Net Inflows & Cap. Outflows & Cap. Inflows \\
\cline { 2 - 4 } Total Volatility & \multicolumn{3}{c}{ Panel I: Total Volatility } \\
\cline { 2 - 4 } Observations & $267.46^{* *}$ & $-233.97^{* *}$ & $170.09^{* *}$ & $-379.55^{* * *}$ \\
$R^{2}$ & $(114.41)$ & $(105.81)$ & $(86.70)$ & $(101.51)$ \\
& 1,664 & 1,532 & 1,664 & 1,691 \\
Global Volatility & 0.66 & 0.57 & 0.50 & 0.40 \\
\cline { 2 - 5 } & Panel II: Country-specific and Global Components of Volatility \\
Country-spec. Vol. & -81.45 & -316.01 & 88.69 & $-874.92^{* * *}$ \\
& $(230.83)$ & $(236.07)$ & $(242.30)$ & $(291.66)$ \\
Observations & $275.70^{* *}$ & $-230.98^{* *}$ & $173.17^{* *}$ & $-360.79^{* * *}$ \\
$R^{2}$ & $(115.77)$ & $(110.45)$ & $(86.71)$ & $(96.42)$ \\
& 1,664 & 1,532 & 1,661 & 1,691 \\
Global Volatility & 0.66 & 0.57 & 0.50 & 0.40 \\
\cline { 2 - 5 } & -33.56 & $-612.35^{* * *}$ & -372.84 & $-648.55^{* *}$ \\
Country-spec. Vol. & $(243.76)$ & $(186.95)$ & $(343.37)$ & $(270.37)$ \\
& $381.91^{* *}$ & $-350.82^{* * *}$ & 18.54 & $-247.96^{*}$ \\
Observations & $(148.55)$ & $(117.62)$ & $(124.96)$ & $(141.13)$ \\
$R^{2}$ & 1,664 & 1,532 & 1,661 & 1,691 \\
\hline \hline
\end{tabular}

Notes: This table reports results from the following panel regressions:

$$
C F_{t}^{i}=\alpha_{i}+\beta_{1} \operatorname{Vol}_{t-1}^{i}+\beta_{2} * C F_{t-1}^{i}+\beta_{3} * C F_{t-2}^{i}+\beta_{4} R_{t-1}^{i}+\beta_{5} * \Delta y_{t-1}^{i}+\beta_{6} \Delta y_{t-2}^{i}+\varepsilon_{t}^{i}
$$

$C F$ denotes capital outflows, inflows, or net inflows. All regressions include country fixed effects, controls (lagged market return $R_{t-1}^{i}$, and two lags of GDP growth, $\Delta y_{t-1}^{i}, \Delta y_{t-2}^{i}$, and lagged values of the dependent variable. Panel I focuses on the impact of total volatility. Panel II reports the different impacts of the country-specific and global components of stock return volatilities. Panel III uses the same variables as in Panel II but adds time fixed-effects to focus on the role of uncertainty betas. The table reports the coefficients $\beta_{1}$, the number of observations and the $R^{2}$. The first column provides the results for net exports, the second column for net inflows, the third column for capital outflows, and the fourth column for capital inflows. All variables are quarterly. The number of observations varies in each regression because of data availability; for each variable, all countries with available data are included. Standard errors are clustered by country and time. Three stars $(* * *)$ denote significance at the $1 \%$ confidence level, while two stars $\left({ }^{*}\right)$ and one $(*)$ star denote significance at the $5 \%$ and $10 \%$ confidence levels. 
volatility shocks is robust to the inclusion of time fixed effects in the panel regressions. We do not find, however, a significant impact of global volatility shocks on real economic activity.

Market-based measures of volatility therefore impact both capital flows and real activity. They are determined in real time, without any look-ahead bias in the researcher's methodology. They are informative about future macroeconomic aggregates certainly because asset markets are forward looking. Many factors may influence these return volatilities. In the rest of this paper, we explore their link, in the data and in a model, to some form of expropriation risk.

\section{Stock Return Volatility and Expropriation Risk}

This section studies the correlation between stock return volatility and expropriation risk. We measure expropriation risk in two ways: through an index of capital account openness and through an index of political risk.

The index of capital account openness comes from Chinn and Ito (2006). They code the restrictions on cross-border financial transactions reported in the IMF's Annual Report on Exchange Arrangements and Exchange Restrictions. A higher level of the index means less restrictions on capital flows. The index of political risk comes from the International Country Risk Guide (ICRG) database, a benchmark in the industry, and used for example in Aguiar, Amador, and Gopinath (2009). We focus on the "Investment Profile." The index combines the risk of expropriation or contract viability, the risk of taxation, repatriation risk, and labor costs risk. A low value of the index means high political risk. Both indices are available for a large cross-section of countries, but only at the annual frequency. We therefore build annual series of volatilities as the four-quarter average of the quarterly series.

Both capital controls and political risk indices appear significantly correlated with countryspecific stock return volatilities, but not with global volatilities. Table 3 reports the correlation between stock return volatility and measures of expropriation risk. Periods of high uncertainty are periods with more restrictions on capital flows and more political risk. This result is intuitive. Governments tend to establish capital controls in times of trouble. Likewise, proposals for taxing 
Table 2: Economic Activity and Volatility Shocks

\begin{tabular}{lccccc}
\hline \hline & GDP & Inv. & Cons. & Ind. Prod. & Empl. \\
\hline \multirow{2}{*}{ Total Volatility } & \multicolumn{5}{c}{ Panel I: Total Volatility } \\
\cline { 2 - 5 } & $-312.79^{* * *}$ & $-626.04^{* * *}$ & $-285.81^{* * *}$ & $-387.70^{* * *}$ & $-802.60^{* *}$ \\
Observations & $(59.23)$ & $(208.48)$ & $(74.40)$ & $(107.72)$ & $(341.49)$ \\
$R^{2}$ & 1,861 & 1,402 & 1,435 & 1,394 & 602 \\
& 0.67 & 0.76 & 0.77 & 0.67 & 0.61 \\
\cline { 2 - 6 } Global Volatility & Panel II: Country-specific and Global Components of Volatility \\
\cline { 2 - 6 } & -101.03 & -517.19 & -26.58 & $-172.82^{*}$ & $-2,236.47$ \\
Country-spec. Vol. & $(104.08)$ & $(362.72)$ & $(103.25)$ & $(94.58)$ & $(1,515.57)$ \\
& $-320.51^{* * *}$ & $-630.62^{* * *}$ & $-297.91^{* * *}$ & $-415.41^{* * *}$ & $-661.68^{* *}$ \\
Observations & $(60.52)$ & $(210.79)$ & $(70.79)$ & $(115.47)$ & $(290.14)$ \\
$R^{2}$ & 1,861 & 1,402 & 1,435 & 1,394 & 602 \\
& 0.67 & 0.76 & 0.77 & 0.67 & 0.61 \\
\cline { 2 - 6 } Global Volatility & 3.81 & -185.63 & 59.81 & -101.76 & 553.71 \\
\cline { 2 - 6 } & $(92.02)$ & $(458.94)$ & $(164.54)$ & $()$. & $(1,744.16)$ \\
Country-spec. Vol. & $-305.98^{* * *}$ & -467.12 & $-273.66 * * *$ & $-295.51^{* * *}$ & -135.01 \\
& $(55.53)$ & $(293.79)$ & $(62.35)$ & $(71.29)$ & $(600.12)$ \\
Observations & 1,861 & 1,402 & 1,435 & 1,394 & 602 \\
$R^{2}$ & 0.72 & 0.80 & 0.81 & 0.76 & 0.68 \\
\hline \hline
\end{tabular}

Notes: This table reports results from the following panel regressions:

$$
\Delta X_{t}^{i}=\alpha_{i}+\beta_{1} V o l_{t-1}^{i}+\beta_{2} * \Delta X_{t-1}^{i}+\beta_{3} * \Delta X_{t-2}^{i}+\beta_{4} R_{t-1}^{i}+\beta_{5} * \Delta y_{t-1}^{i}+\beta_{6} \Delta y_{t-2}^{i}+\varepsilon_{t}^{i}
$$

$X$ denotes GDP, investment, consumption, industrial production, and (the opposite of) the unemployment rate. All regressions include country fixed effects, controls (lagged market return $R_{t-1}^{i}$, and two lags of GDP growth, $\Delta y_{t-1}^{i}, \Delta y_{t-2}^{i}$, and lagged values of the dependent variable. Panel I focuses on the impact of total volatility. Panel II reports the different impacts of the country-specific and global components of stock return volatilities. Panel III uses the same variables as in Panel II but adds time fixed-effects to focus on the role of uncertainty betas. The table reports the coefficients $\beta_{1}$, the number of observations and the $R^{2}$. All variables are quarterly. GDP, investment, consumption, industrial production are expressed as log year-on-year differences. The number of observations varies in each regression because of data availability; for each variable, all countries with available data are included. Standard errors are clustered by country and time. Three stars $\left(^{* *}\right)$ denote significance at the $1 \%$ confidence level, while two stars $(* *)$ and one $(*)$ star denote significance at the $5 \%$ and $10 \%$ confidence levels. 
Table 3: Stock Return Volatility and Expropriation Risk

\begin{tabular}{lcccc}
\hline \hline & Vol. & Vol. & Vol. & Vol \\
\hline Capital Account Openness & $-0.120^{* *}$ & $-0.130^{* * *}$ & & \\
& $(0.053)$ & $(0.048)$ & & \\
Investment Profile & & & $-0.115^{* * *}$ & $-0.081^{* * *}$ \\
& & & $(0.033)$ & $(0.026)$ \\
Observations & 552 & 552 & 404 & 404 \\
$R^{2}$ & 0.068 & 0.324 & 0.116 & 0.378 \\
Country Fixed Effects & $\mathrm{n}$ & $\mathrm{y}$ & $\mathrm{n}$ & $\mathrm{y}$ \\
\hline \hline
\end{tabular}

Notes: This table reports results from the following panel regressions:

$$
V o l_{t}^{i}=\alpha_{i}+\beta_{1} X_{t-1}^{i}+\varepsilon_{t}^{i}
$$

where $V$ ol denotes the country-specific stock return volatility and $X$ denotes the Chinn-Ito (2008) or the ICRG Political Risk index. Regressions include or not country fixed effects. The table reports the coefficients $\beta_{1}$, the number of observations and the $R^{2}$. All variables are annual. The number of observations varies in each regression because of data availability; for each variable, all countries with available data are included. Standard errors are clustered by country and time. Three stars $(* * *)$ denote significance at the $1 \%$ confidence level, while two stars $(* *)$ and one $(*)$ star denote significance at the $5 \%$ and $10 \%$ confidence levels.

foreigners tend also to be discussed in times of trouble. We do not establish, however, any causal link in the data; we only report correlations. Because of the annual frequency, we can not precisely study any lead-lag relationship either. But there is a very strong correlation between stock market return volatility and some form

Building on this evidence, we propose a simple model of gross capital flows.

\section{A Simple Model of Gross Capital Flows with Expropri- ation Risk}

This section introduces a simple equilibrium model of optimal portfolio choice to interpret the evidence uncovered in the previous sections. This evidence requires generating sharp movements in opposite direction of gross inflows (i.e., net sales of domestic assets by foreigners) and gross 
outflows (i.e., net sales of domestic assets by residents). This is challenging because in general a shock, such as a change in the riskiness of the assets of the two countries, would lead both foreigners and residents to change their portfolio allocation in the same direction. The model reflects our first attempt at breaking this symmetry: we assume that foreigners differ from residents in that they face expropriation risk. This expropriation risk varies stochastically over time. The model then studies the effect of exogenous changes in the riskiness of different countries on gross international capital flows. We first present the model setup, then discuss briefly the solution method, and finally report some preliminary simulation results.

\subsection{Model Setup}

The model is an endowment economy with two countries, one representative agent in each country, and a single good (the same good in both countries). A star * denotes a foreign variable. In each country, a tree produces dividends, denoted $\left\{D_{t}\right\}$ for the home tree and $\left\{D_{t}^{\star}\right\}$ for the foreign tree. Both $\left\{D_{t}\right\}$ and $\left\{D_{t}^{\star}\right\}$ follow exogenous stochastic processes. There are no trade costs and no labor income. We denote by $P$ and $P^{\star}$ the price of one share of the domestic and foreign tree respectively, and by $S^{i, j}$ the number of units of of tree $j$ held by agent $i$, i.e. the share of tree $j$ owned by $i$. Hence $S^{f, h}$ is the share of home tree held by the foreign agent.

In each country, the representative agent has standard expected utility preferences. The home representative agent, for example, maximizes:

$$
\max _{\left\{C_{t}, S_{t+1}^{h, h}, S_{t+1}^{h, f}\right\}} E_{0} \sum_{t=0}^{\infty} \beta^{t} \frac{C_{t}^{1-\gamma}}{1-\gamma}
$$

by choosing (1) how much to consume $\left(C_{t}\right)$ and (2) how many shares of the domestic $\left(S^{h, h}\right)$ and foreign $\left(S^{h, f}\right)$ trees to buy, subject to a budget constraint described below. The foreign representative agent solves a similar maximization problem. Thus far, the model describes a classic two-tree portfolio optimization problem.

We depart from the frictionless two-tree portfolio problem by introducing expropriation risk, which takes the form of a stochastic tax on the foreigners' holdings of domestic capital. To keep 
the model simple, we assume that assets invested in the foreign country are not exposed to any expropriation, and that domestic residents are not subject to expropriation risk either. The proceeds from this tax are used either for government spending, or are rebated as lump-sum transfers to the domestic agents and the foreigners. ${ }^{5}$

The tax rate, denoted $\tau_{t}$, depends on the state of the economy as follows:

$$
\tau_{t}=\left\{\begin{array}{ll}
0 & \text { with probability } 1-p_{t} \\
1-\exp \left(-\lambda S_{t}^{f, h}\right) & \text { with probability } p_{t}
\end{array}\right\}
$$

Intuitively, a larger share of foreign assets held by foreigners increases the incentives to expropriate them. More technically, this formulation implies that the tax rate disappears as the foreigner share goes to zero, and hence helps ensure that the equilibrium does not hit corner solutions. Last, expropriation is a low probability event: the tax rate is zero with probability $1-p_{t}$ and strictly positive with probability $p_{t}$. The probability of expropriation $p_{t}$, drawn at time $t-1$, follows an autoregressive process. The proceeds from the expropriation are denoted by $R_{t}$. They correspond to the product of the tax rate times the tax base, which is itself governed by the shares held times their (cum-dividend) price: $R_{t}=\tau_{t} S_{t}^{f, h}\left(P_{t}+D_{t}\right)$.

Given these assumptions, the budget constraints of the home and foreign investors are respectively:

$$
C_{t}+P_{t} S_{t+1}^{h, h}+P_{t}^{\star} S_{t+1}^{h, f}=\left(P_{t}+D_{t}\right) S_{t}^{h, h}+\left(P_{t}^{*}+D_{t}^{\star}\right) S_{t}^{h, f}+\alpha_{2} R_{t},
$$

and

$$
C_{t}^{\star}+P_{t} S_{t+1}^{f, h}+P_{t}^{\star} S_{t+1}^{f, f}=\left(1-\tau_{t}\right)\left(P_{t}+D_{t}\right) S_{t}^{f, h}+\left(P_{t}^{\star}+D_{t}^{\star}\right) S_{t}^{f, f}+\alpha_{3} R_{t}
$$

where $\alpha_{2}$ and $\alpha_{3}$ denote the share of expropriation proceeds that are rebated lump-sum to domestic and foreign investors respectively. Finally, the market clearing conditions for goods and assets

\footnotetext{
${ }^{5}$ In a variant of the model, the transfers to the domestic agents could be set in proportion to their holdings of securities.
} 
impose that:

$$
\begin{aligned}
S_{t}^{h, h}+S_{t}^{f, h} & =1, \\
S_{t}^{h, f}+S_{t}^{f, f} & =1, \\
C_{t}+C_{t}^{\star} & =D_{t}+D_{t}^{\star}-\alpha_{1} R_{t},
\end{aligned}
$$

where $\alpha_{1}$ denotes the share of expropriation proceeds that is spent by the government.

\subsection{Solution, Calibration, and Simulation Method}

We first describe the system of equations that characterize the equilibrium. We then explain our numerical solution method and our choice for stochastic processes. Finally, we discuss briefly our parameters.

Equilibrium conditions Assuming the existence of an interior solution, the maximization problems of the home and foreign agents imply the following four first-order conditions:

$$
\begin{aligned}
P_{t} u^{\prime}\left(C_{t}\right) & =\beta E_{t}\left[\left(P_{t+1}+D_{t+1}\right) u^{\prime}\left(C_{t+1}\right)\right] \\
P_{t}^{\star} u^{\prime}\left(C_{t}\right) & =\beta E_{t}\left[\left(P_{t+1}^{\star}+D_{t+1}^{\star}\right) u^{\prime}\left(C_{t+1}\right)\right] \\
P_{t} u^{\prime}\left(C_{t}^{\star}\right) & =\beta E_{t}\left[\left(P_{t+1}^{\star}+D_{t+1}^{\star}\right) u^{\prime}\left(C_{t+1}^{\star}\right)\right] \\
P_{t}^{\star} u^{\prime}\left(C_{t}^{\star}\right) & =\beta E_{t}\left[\left(1-\tau_{t+1}\right)\left(P_{t+1}+D_{t+1}\right) u^{\prime}\left(C_{t+1}^{\star}\right)\right] .
\end{aligned}
$$

The first two equations correspond to the optimal portfolio choice of the home investor, while the last two equations correspond to the optimal portfolio choice of the foreign investor. Those four equations coupled with the feasibility constraints, the clearing market conditions, and a budget constraint summarize the model.

Numerical Solution Method The model is solved using projection methods similar to Judd (1992) and Aruoba, Fernandez-Villaverde and Rubio-Ramirez (2006), following the steps outlined 
in Rabitsch, Stepanchuk and Tsyrennikov (2014). In simple portfolio models, the only endogenous state variable is the relative wealth of the agents. In our case, because the tax proceeds $R_{t}$ depend on the foreign-held share of the domestic asset, an additional state variable is necessary to describe the model solution. For simplicity, we pick this share as our second state variable. The method solves for six policy functions, which depend on the two endogenous state variables as well as the exogenous shocks. These shocks are discretized and approximated through Markov chains. We approximate the six policy functions by (tensor of) Chebyshev polynomials. The precise implementation of the projection method is described in the Appendix.

The process for exogenous variables The dividend dynamics are described by two exogenous state variables $\left(D_{t}\right.$ and $\left.D_{t}^{\star}\right)$ :

$$
\left(\begin{array}{c}
D_{t+1} \\
D_{t+1}^{\star}
\end{array}\right)=\left(\begin{array}{c}
\bar{D} \\
\bar{D}
\end{array}\right)+A\left(\begin{array}{c}
D_{t} \\
D_{t}^{\star}
\end{array}\right)+\varepsilon_{t+1}
$$

where the shocks $\varepsilon_{t+1}$ are $i . i . d$ and normally distributed according to a $N(0, \Sigma)$ distribution.

Calibration Table 4 describes the model parameters. The risk-aversion coefficient is set to 1 , while the discount factor is set to 0.9. The autoregressive coefficient of the dividend level is equal to 0.1. The expropriation proceeds are either wasted (33\%), or rebated to home and foreign investors (33\% each). The tax rate sensitivity is set to $10^{-5}$. We view this calibration as preliminary.

\subsection{Simulation Results}

Let us first describe the model equilibrium before turning to the impulse response functions to expropriation probability shocks. As foreign investors become relatively wealthier, their holdings of both trees and their consumption increase, whereas the opposite happens to domestic investors. ${ }^{6}$

\footnotetext{
${ }^{6}$ Figure 4 in the Online Appendix reports the foreign and domestic consumption, the prices of the foreign and domestic trees, as well as the foreign and domestic shares of the two trees, all as a function of the share of the domestic tree held by foreign investors. This share mimics the relative wealth of foreign investors.
} 
Table 4: Calibration

\begin{tabular}{lcc}
\hline \hline Model parameter & Notation & Value \\
\hline Risk-aversion & $\gamma$ & 1.0 \\
Discount factor & $\beta$ & 0.9 \\
Average dividend & $\bar{D}$ & 1.0 \\
Persistence of dividend & $a$ & 0.1 \\
Volatility and cross-country correlation & $\Sigma$ & {$\left[\begin{array}{cc}0.5 & -0.05 \\
-0.05 & 0.5\end{array}\right]$} \\
Tax rate sensitivity & $\lambda$ & {$[0.33,0.33,0.33]$} \\
Lump-sum rebates & $\lambda$ & {$\left[\begin{array}{ll}0.05,0.01, & 0.6\end{array}\right]$} \\
Mean, persistence, and vol. of expr. prob. & $\bar{p}, \rho, \sigma$ & $\left.\alpha_{2}, \alpha_{3}\right]$ \\
\hline \hline
\end{tabular}

Notes: The law of motion of dividend is:

$$
\left(\begin{array}{c}
D_{t+1} \\
D_{t+1}^{\star}
\end{array}\right)=\left(\begin{array}{c}
\bar{D} \\
\bar{D}
\end{array}\right)+A\left(\begin{array}{c}
D_{t} \\
D_{t}^{\star}
\end{array}\right)+\varepsilon_{t+1}
$$

where $A$ is a diagonal matrix with $a$ as diagonal values and the shocks $\varepsilon_{t+1}$ are i.i.d and normally distributed according to a $N(0, \Sigma)$ distribution. The expropriation probability $p_{t}$ follows a recursive process: $p_{t+1}=(1-\rho) \bar{p}+$ $\rho p_{t}+u_{t+1}$, where the shocks $u_{t+1}$ are $i . i . d$ and normally distributed according to a $N\left(0, \sigma^{2}\right)$ distribution.

As foreign investors become relatively wealthier, the foreign tree becomes more expensive, whereas the home tree becomes less expensive.

Figure 1 reports the same variables as a function of the expropriation probability. Consumption does not move, but prices and holdings change with the level of expropriation risk. When the expropriation probability increases, foreign investors want to hold a lower share of the domestic tree and a larger share of the foreign tree. The price of the domestic tree declines, while the price of the foreign tree increases.

These equilibrium functions explain the dynamics of the impulse response functions described in Figure 2. There, the probability of an expropriation in the future increases initially and then mean-reverts slowly. The foreign agent sells some of her holdings of the domestic tree to the domestic agent, who is immune to the expropriation risk. The foreigner's share of the home tree decreases while her share of the foreign tree increases. Because of the market clearing condition, the share of the foreign tree held by the domestic agent must therefore decline. Capital flows in 

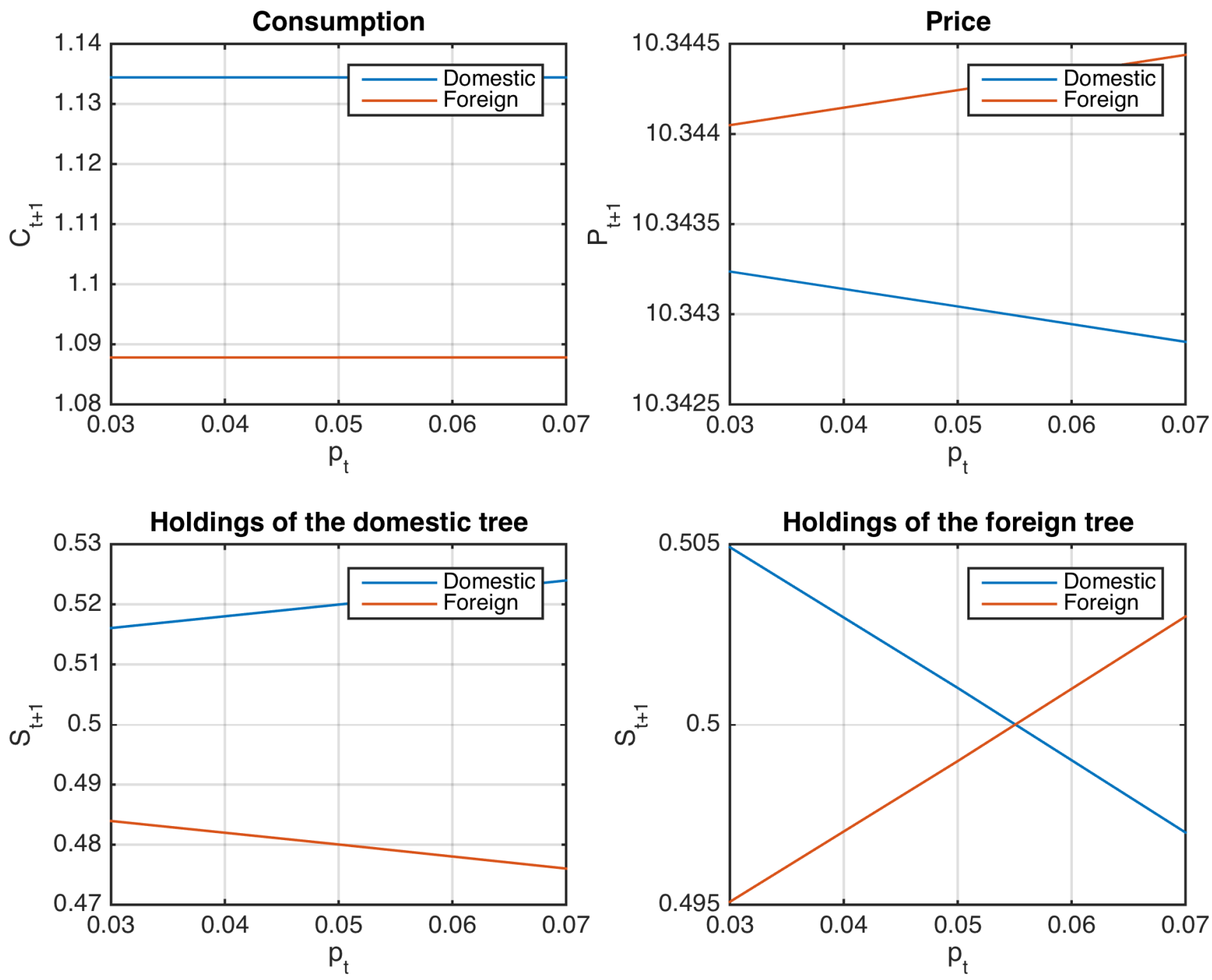

Figure 1: Model Equilibrium: Consumption, Price and Shares of the Trees as a Function of Expropriation Probability — The model is simulated with the parameters described in Table 4. 
the model can be measured as $P_{t}^{\star} S_{t+1}^{h f}-P_{t-1}^{\star} S_{t}^{h f}$ : they correspond to the value of the foreign tree held by the domestic agent at date $t+1$ minus the value of the foreign tree held by the domestic agent at date $t$. Since the domestic agent is buying her own tree and selling the foreign tree, the home country (which is exposed to expropriation risk) first experiences large capital outflows.

A price effect then kicks in. The price of the domestic tree decreases to reflect its riskiness. The price of the foreign tree increases to clear the demand. When the expropriation probability reverts back to its initial level, the home country then experiences capital inflows, but those flows are in magnitude smaller than the previous capital outflows. The lower size of capital inflows than outflows is due to a price effect: the home tree is cheaper than it used to be. Therefore going back to the previous equilibrium portfolio allocation requires less capital flows.

How does the model compare to the data? Let us first consider the dynamics of capital flows and then the cross-country differences. The model-based impulse response function appears similar to the impulse response function obtained on actual data when considering a shock to total stock return volatility. Figure 3 presents the data counterpart. The impulse response functions are estimated by local projections following Jorda (2005). On average, emerging countries first experience negative net inflows after a spike in stock return volatility. The net inflows are the most negative after two quarters. After four quarters, net inflows change sign, emerging countries tend to experience positive net inflows but their absolute value is lower than the initial outflows.

The model features only one country subject to expropriation risk, but comparative statics help interpret actual data on cross-country differences. In the model, the larger the expropriation risk $(\lambda)$, the larger the stock price changes, and the larger the capital flows response. In the logic of the model, the initial shock is the increase of the expropriation probability. This shock affects equity prices, increasing their volatility, and money flows out of the country because foreign investors fear being taxed.

The model so far does not distinguish between country-specific and global volatility. Doing so would require the definition of global shocks. One could easily imagine that the expropriation probability has two components: a global component, common to all countries, and a country- 

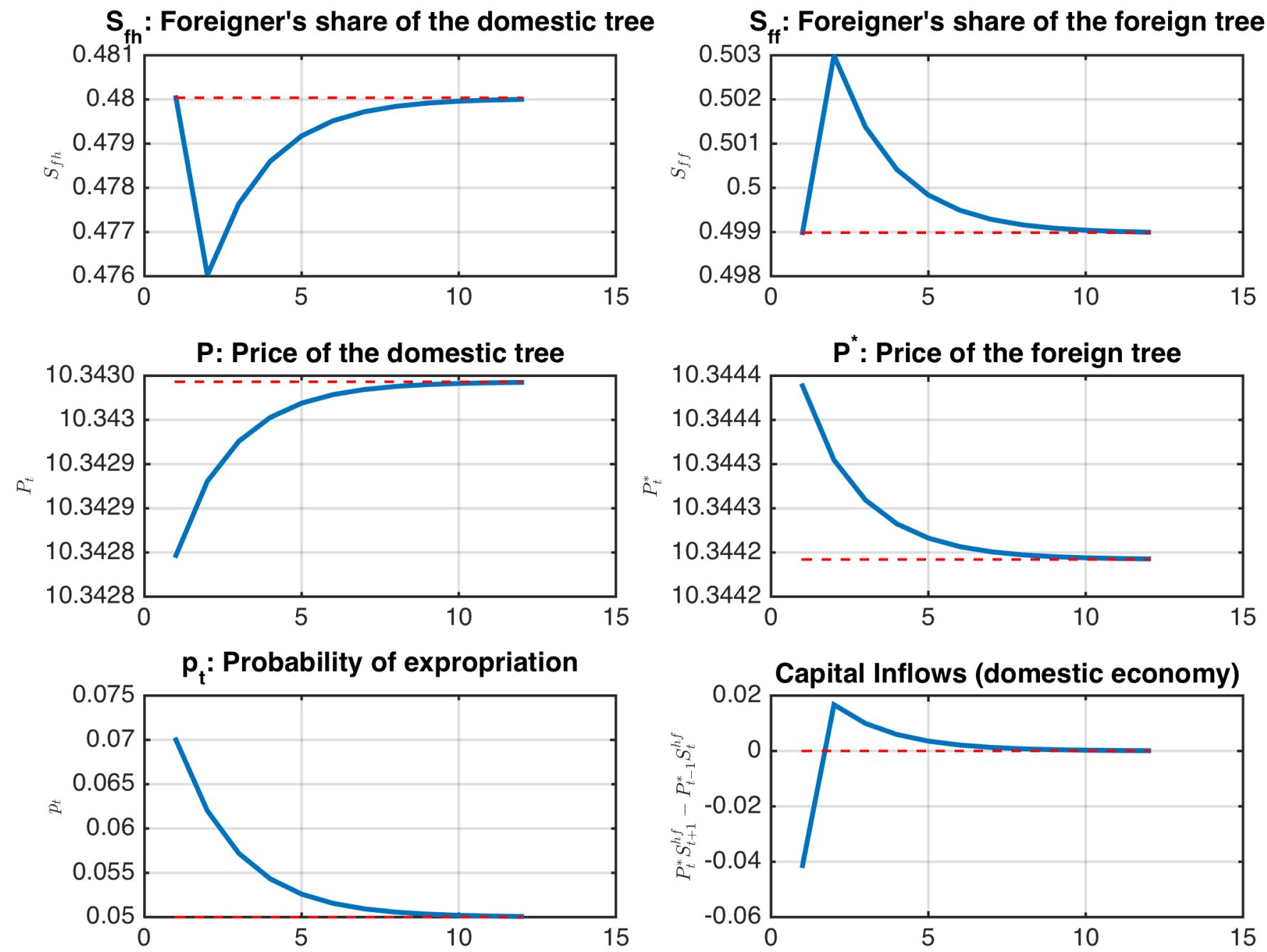

Figure 2: Impulse Response Functions: Expropriation Probability Shock — The model is simulated with the parameters described in Table 4. 


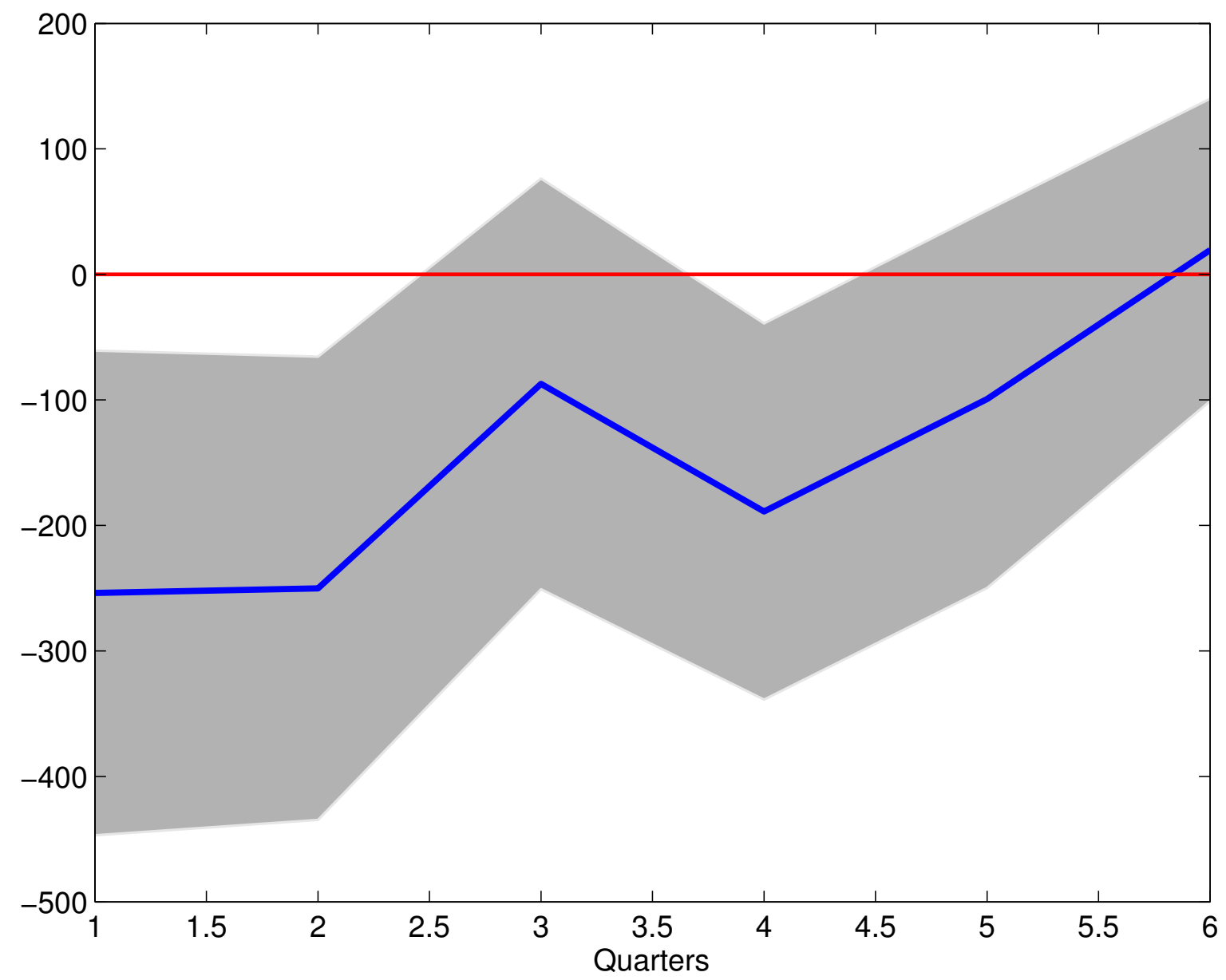

Figure 3: Impulse Response Function in the Data - The impulse response functions are estimated by local projections following Jorda (2005). They correspond to the average responses of net capital inflows to a shocks on total volatility in each country. The standard errors and confidence bands at each horizon take into account the uncertainty stemming from all horizons. 
specific component. For the sake of clarity, shocks on the expropriation probability are orthogonal to the endowment shocks in the model. They are certainly correlated in the data: governments consider expropriation measures in bad times, not in good times. Therefore, along with the two components of expropriation probability, global and country-specific shocks could be introduced on endowments. The model then would interpret differences in uncertainty betas in terms of differences in the size of expropriation risk. A high volatility beta thus corresponds to a higher level $\lambda$ of expropriation risk linked to global shocks.

The model therefore suggests a potential interpretation of the capital flows dynamics. The model calibration, however, has several weaknesses. The model does not reproduce fully the equity home bias in the data: while the U.S. stock market represents close to a third of the world stock market, actual U.S. investors tend to allocate more than two-thirds of their assets to U.S. stocks. The model does not reproduce the level of the price-dividend ratio or the average equity return in the data. The model does not reproduce the volatility of equity prices or capital flows. To sum up, the current calibration offers a qualitative but not quantitative interpretation of the data.

\subsection{Potential Extensions}

Three different extensions can be considered. First, the representative investor could be characterized by Epstein-Zin (1989) preferences instead of constant relative risk-aversion. By disentangling the coefficient of risk aversion and the inter-temporal elasticity of substitution (IES) the model could then feature large expected equity returns (due to high risk aversion) and equity drop prices when volatility increases (due to high IES). Second, the model could feature different goods across countries and home bias in consumption (as in Heathcote and Perri, 2013). The introduction of exchange rate risk and home bias in consumption would help the model reproduce the well-known equity home bias. Third, the set of assets traded could include domestic and foreign bonds along the two equity claims. As Coeurdacier and Gourinchas (2011) show, in the presence of exchange rate risk, the introduction of such bonds has a large impact on the optimal portfolio allocation. 


\section{Conclusion}

This paper documents that economic uncertainty has a significant impact on international capital flows for a large set of emerging countries. We measure economic uncertainty through the volatility of stock market returns, and distinguish between total, country-specific and systematic volatilities. An increase in economic uncertainty increases gross capital outflows and decreases gross capital inflows. The effect on international capital inflows is stronger for countries that have a higher exposure to global stock market volatility. We develop a simple model in which home and foreign investors behave differently because foreign investors face some expropriation risk. The model is able to generate qualitatively the effect of uncertainty on capital flows.

\section{References}

Aguiar, Mark, Manuel Amador, and Gita Gopinath, "Investment cycles and sovereign debt overhang," The Review of economic studies, 2009, 76 (1), 1-31.

Ahmed, Shaghil and Andrei Zlate, "Capital flows to emerging market economies: a brave new world?," Working Paper Federal Reserve Board, 2012.

Albuquerque, Rui, Gregory H Bauer, and Martin Schneider, "International equity flows and returns: a quantitative equilibrium approach," The Review of Economic Studies, 2007, $74(1), 1-30$.

Arellano, Cristina, Yan Bai, and Patrick J Kehoe, "Financial frictions and fluctuations in volatility," Federal Reserve Bank of Minneapolis Research Department Staff Report, 2012, 466.

Aruoba, S.B., J. Fernandez-Villaverde, and J.F. Rubio-Ramirez, "Comparing Solution Methods for Dynamic Equilibrium Economies," Journal of Economic Dynamics and Control, 2006, 30 (12), 2477-2508. 
Bachmann, Ruediger, Steffen Elstner, and Eric Sims, "Uncertainty and Economic Activity: Evidence from Business Survey Data," American Economic Journal: Macroeconomics, 2013, $5(2), 217-49$.

Backus, David, Espen Henriksen, Frederic Lambert, and Christopher Telmer, "Current account fact and fiction," Working Paper National Bureau of Economic Research, 2009.

Baker, Scott R and Nicholas Bloom, "Does uncertainty reduce growth? Using disasters as natural experiments," NBER Working Paper, 2013.

Bansal, Ravi and Amir Yaron, "Risks for the Long Run: A Potential Resolution of Asset Pricing Puzzles," Journal of Finance, 2004, 59 (4), 1481 - 1509.

, Varoujan Khatchatrian, and Amir Yaron, "Interpretable asset markets?," European Economic Review, 2005, 49 (3), 531-560.

Bekaert, Geert, Marie Hoerova, and Marco Lo Duca, "Risk, uncertainty and monetary policy," Journal of Monetary Economics, 2013, 60 (7), 771-788.

Bhamra, Harjoat S, Nicolas Coeurdacier, and Stéphane Guibaud, "A dynamic equilibrium model of imperfectly integrated financial markets," Working Paper, 2012.

Bloom, Nicholas, "The impact of uncertainty shocks," Econometrica, 2009, 7 ry (3), 623-685.

_ , "Fluctuations in Uncertainty," NBER Working Paper, 2013.

, Max Floetotto, Nir Jaimovich, Itay Saporta-Eksten, and Stephen J Terry, "Really uncertain business cycles," NBER Working Paper, 2012.

Bluedorn, John, Rupa Duttagupta, Jaime Guajardo, and Petia Topalova, "Capital Flows are Fickle: Anytime, Anywhere," 2013. Working Paper, I.M.F.

Broner, Fernando, Tatiana Didier, Aitor Erce, and Sergio L. Schmukler, "Gross capital flows: Dynamics and crises," Journal of Monetary Economics, 2013, 60, 113-133. 
Bruno, Valentina and Hyun Song Shin, "Cross-Border Banking and Global Liquidity," The Review of economic studies, forth., 2014.

Caballero, Ricardo J and Emmanuel Farhi, "The Safety Trap," 2014. National Bureau of Economic Research.

_ _ _ and Pierre-Olivier Gourinchas, "An Equilibrium Model of "Global Imbalances" and Low Interest Rates," American Economic Review, 2008, 98 (1), 358-393.

Calvo, Guillermo A, "Capital Flows and Capital Market Crises: The Simple Economics of Sudden Stops.," Journal of applied Economics, 1998, 1 (1).

, Alejandro Izquierdo, and Ernesto Talvi, "Phoenix miracles in emerging markets: recovering without credit from systemic financial crises," NBER Working Paper, 2006.

_ _ _ and _ _ _ "Sudden stops and phoenix miracles in emerging markets," American Economic Review, 2006, pp. 405-410.

Cameron, A Colin, Jonah B Gelbach, and Douglas L Miller, "Robust inference with multiway clustering," Journal of Business 63 Economic Statistics, 2011, 29 (2).

Carrière-Swallow, Yan and Luis Felipe Céspedes, "The impact of uncertainty shocks in emerging economies," Journal of International Economics, 2013, 90 (2), 316-325.

Cerutti, E., S. Claessens, and L. Ratnovski, "Global Liquidity and Drivers of Cross-Border Bank Flows," 2014. IMF working paper.

Chang, Yongsung, Sun-Bin Kim, and Jaewoo Lee, "Accounting for global dispersion of current accounts," Review of Economic Dynamics, 2013, 16 (3), 477 - 496.

Chinn, Menzie D and Hiro Ito, "What matters for financial development? Capital controls, institutions, and interactions," Journal of Development Economics, 2006, 81 (1), 163-192. 
Choe, Hyuk, Bong-Chan Kho, and René M Stulz, "Do domestic investors have an edge? The trading experience of foreign investors in Korea," Review of Financial Studies, 2005, 18 (3), 795-829.

Christiano, Lawrence, Massimo Rostagno, and Roberto Motto, "Financial factors in economic fluctuations," Working Paper European Central Bank, 2010, 1192.

Coeurdacier, Nicolas and Pierre-Olivier Gourinchas, "When Bonds Matter: Home Bias in Goods and Assets," NBER Working Papers, National Bureau of Economic Research, Inc November 2011.

, Hélène Rey, and Pablo Winant, "The Risky Steady State," American Economic Review, 2011, $101(3), 398-401$.

, and _ _ , "Financial integration and growth in a risky world," Working Paper, 2013.

Colacito, Riccardo and Mariano Croce, "The short-and long-run benefits of financial integration," in "American Economic Review, Papers and Proceedings" 2010.

and Mariano M Croce, "International asset pricing with risk-sensitive agents," 2011. Working paper, University of North Carolina.

, Mariano Massimiliano Croce, Steven Ho, and Philip Howard, "BKK the EZ Way: An international production economy with recursive preferences," Working paper, University of North Carolina, 2013.

Devereux, Michael B. and Alan Sutherland, "Valuation Effects and the Dynamics of Net External Assets," Journal of International Economics, 2010, 80 (1), 129-143.

Durdu, Ceyhun Bora, Enrique G Mendoza, and Marco E Terrones, "Precautionary demand for foreign assets in Sudden Stop economies: An assessment of the New Mercantilism," Journal of Development Economics, 2009, 89 (2), 194-209. 
Edwards, S., "Financial openness, sudden stops, and current-account reversals," American Economic Review, 2004, 94 (2), 59-64.

Edwards, Sebastian, "Does the current account matter?," in "Preventing currency crises in emerging markets," University of Chicago Press, 2002, pp. 21-76.

Epstein, Larry G. and Stanley Zin, "Substitution, Risk Aversion and the Temporal Behavior of Consumption and Asset Returns: A Theoretical Framework," Econometrica, 1989, 57, 937-969.

Fernández-Villaverde, J., P. Guerrón-Quintana, J.F. Rubio-Ramirez, and M. Uribe, "Risk matters: The real effects of volatility shocks," American Economic Review, 2011, 101 (6), 2530-2561.

Fogli, Alessandra and Fabrizio Perri, "Macroeconomic volatility and external imbalances," Manuscript, Federal Reserve Bank of Minneapolis, 2006.

Forbes, Kristin J. and Francis E. Warnock, "Capital Flow Waves: Surges, Stops, Flight and Retrenchment," Journal of International Economics, 2012, 88 (2), 235-251.

Fornaro, Luca, "International debt deleveraging," 2014. Working Paper CREI.

Fratzscher, Marcel, "Capital flows, push versus pull factors and the global financial crisis," Journal of International Economics, 2012, 88 (2), 341-356.

Gabaix, Xavier, "Variable Rare Disasters: An Exactly Solved Framework for Ten Puzzles in Macro-Finance," Quarterly Journal of Economics, 2012, 127 (2), 645-700.

and Matteo Maggiori, "International liquidity and exchange rate dynamics," 2014. National Bureau of Economic Research.

Gilchrist, Simon, Jae Sim, and Egon Zakrajsek, "Uncertainty, credit spreads, and investment dynamics," Working Paper Boston University, 2009. 
Gourinchas, Pierre-Olivier and Hélène Rey, "From world banker to world venture capitalist: US external adjustment and the exorbitant privilege," in "G7 Current Account Imbalances: Sustainability and Adjustment," University of Chicago Press, 2007, pp. 11-66.

and __ , "International Financial Adjustment," Journal of Political Economy, 2007, 115 (4), 665-703.

, Hélène Rey, and Kai Truempler, "The financial crisis and the geography of wealth transfers," Journal of International Economics, 2012, 88 (2), 266-283.

, Hélène Rey, and Nicolas Govillot, "Exorbitant Privilege and Exorbitant Duty," 2010. Working Paper.

Gourio, Francois, "Disaster Risk and Business Cycles," American Economic Review, 2012, 102(6), 2734-66.

, Michael Siemer, and Adrien Verdelhan, "International Risk Cycles," Journal of International Economics, 2013, 89, 471-484.

Heathcote, Jonathan and Fabrizio Perri, "The International Diversification Puzzle Is Not as Bad as You Think," Journal of Political Economy, 2013, 121 (6), 1108 - 1159.

Jorda, Oscar, "Estimation and Inference of Impulse Responses by Local Projections," American Economic Review, 2005, 95 (1), 161-182.

Judd, Kenneth L., "Projection Methods for Solving Aggregate Growth Models," Journal of Economic Theory, 1992, 58 (2), 410-452.

Kalemli-Ozcan, Sebnem, Elias Papaioannou, and Fabrizio Perri, "Global banks and crisis transmission," Journal of International Economics, 2013, 89 (2), 495-510.

Kelly, Bryan, Hanno Lustig, and Stijn Van Nieuwerburgh, "Firm Volatility in Granular Networks," NBER Working Paper, 2013. 
Kim, Woochan and Shang-Jin Wei, "Foreign portfolio investors before and during a crisis," Journal of international economics, 2002, 56 (1), 77-96.

Kollmann, Robert, "Exchange Rates Dynamics with Long-Run Risk and Recursive Preferences," Open Economies Review, forth., 2015.

Lane, Philip R and Gian Maria Milesi-Ferretti, "The external wealth of nations mark II: Revised and extended estimates of foreign assets and liabilities, 1970-2004," Journal of international Economics, 2007, 73 (2), 223-250.

Maggiori, Matteo, "Financial Intermediation, International Risk Sharing, and Reserve Currencies," 2012. Working Paper, Harvard University.

Mendoza, Enrique G, Vincenzo Quadrini, and Jose-Vıctor Rıos-Rull, "Financial Integration, Financial Development, and Global Imbalances," Journal of Political Economy, 2009, $117(3)$.

Milesi-Ferretti, Gian-Maria and Cédric Tille, "The great retrenchment: international capital flows during the global financial crisis," Economic Policy, 2011, 26 (66), 289-346.

Miranda-Agrippino, Silvia and Hélène Rey, "World Asset Markets and the Global Financial Cycle," 2014. Working Paper, London Business School.

Obstfeld, Maurice, "Does the Current Account Still Matter?," 2012. NBER Working Paper.

_ _ "Financial flows, financial crises, and global imbalances," Journal of International Money and Finance, 2012, 31 (3), 469-480.

Petersen, Mitchell A, "Estimating standard errors in finance panel data sets: Comparing approaches," Review of financial studies, 2009, 22 (1), 435-480.

Rabitsch, Katrin, Serhiy Stepanchuk, and Viktor Tsyrennikov, "International portfolios: A comparison of solution methods," Working Paper WU Vienna University of Economics and Business, 2014. 
Rey, Hélène, "Dilemma not Trilemma: The global financial cycle and monetary policy independence," in "Jackson Hole Economic Symposium" 2013.

Rothenberg, Alexander D and Francis E Warnock, "Sudden flight and true sudden stops," Review of International Economics, 2011, 19 (3), 509-524.

Schaal, Edouard, "Uncertainty, productivity and unemployment in the great recession," Federal Reserve Bank of Minneapolis, mimeo, 2012.

Segal, Gill, Ivan Shaliastovic, and Amir Yaron, "Good and Bad Uncertainty: Macroeconomic and Financial Market Implications," Working Paper University of Pennsylvania, 2014.

Tille, Cedric and Eric Van Wincoop, "International capital flows," Journal of international Economics, 2010, 80 (2), 157-175. 


\section{- Supplementary Online Appendix - NOT FOR PUBLICATION}

This appendix presents the literature on uncertainty in closed economies in Appendix A, our data in Appendix B, and the simulation method in Appendix C.

\section{Appendix A Literature}

The literature review in the main text focuses on open economy studies. We rapidly review here the most recent work on closed economies.

Bansal and Yaron (2004) and Bansal, Khatchatrian, and Yaron (2005) are early examples of the role of heteroscedasticity in macro-finance/ In Bloom (2009) and Bloom, Floetotto, Jaimovich, SaportaEksten and Terry (2012), the combination of economic uncertainty with real adjustment costs induce firms to behave cautiously, implying a drop in economic activity. Gilchrist, Sim and Zakrajsek (2009) provide evidence that increases in uncertainty lead to prolonged declines in investment activity due to increases in financing costs. Arellano, Bai and Kehoe (2012) argue that an increase in risk leads firms to reduce their inputs as financial frictions limit firms' ability to insure against such shocks. Schaal (2012) study uncertainty shocks in a search and matching model of employment, applied notably to the financial crisis of 2007-2009. Bachmann, Elstner and Sims (2013) show that the impact of uncertainty shock is more persistent in the United States than in Germany. Fernández-Villaverde, Guerrón-Quintana, Rubio-Ramirez and Uribe (2011) report that increases in the volatility of real interest rates of small open economics lead to a decline in economic activity. Baker and Bloom (2013) argue that uncertainty shocks can account for about half the variation in economic growth. Bekaert, Hoerova and Lo Duca (2013) decompose the stock market option-based implied volatility index (VIX) into a proxy for risk aversion and economic uncertainty. They argue that lax monetary policy decreases both uncertainty as well as a risk aversion. Segal, Shaliastovich, and Yaron (2014) decompose uncertainty into "good" and "bad" uncertainty. They argue that "good" uncertainty increases economic activity while "bad" uncertainty predicts lower economic growth. Kelly, Lustig, and van Nieuwerburgh (2013) develop a network model of firm volatility that can generate the observed firm level volatility distribution dynamics in the data. Christiano, Rostagno and Motto (2010) add a financial market and a banking sector to 
a standard monetary DSGE model. Shocks to uncertainty generate significant reductions in output. Gabaix (2012) and Gourio (2012) offer potential alternative interpretations of uncertainty shocks in terms of shocks to disaster probabilities.

\section{Appendix B Data}

Table 5 report the starting year of all series in our sample. 


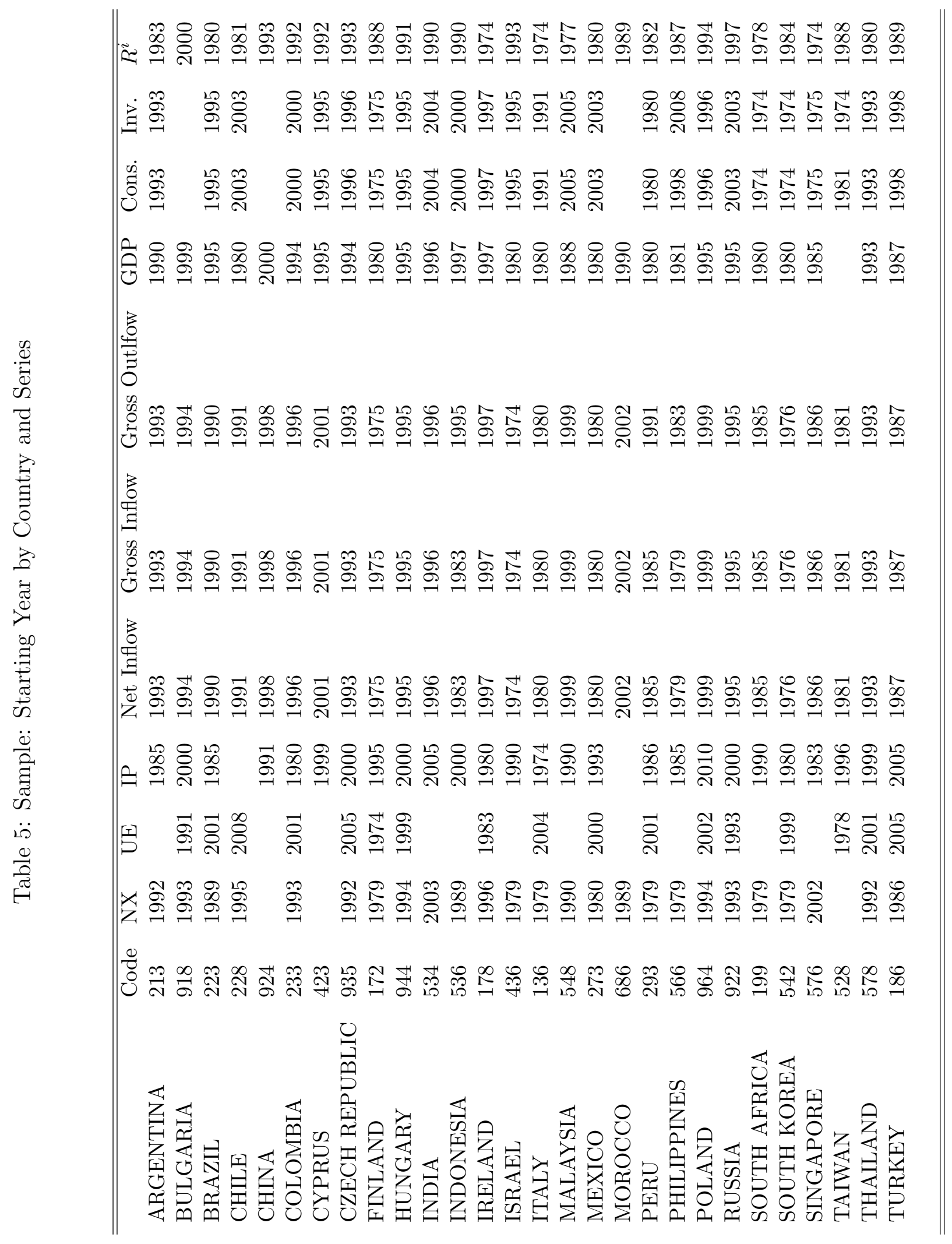




\section{Appendix C Model Simulations}

Let $\omega$ denote the relative wealth and $x$ the expropriation event. Recall that $S^{f, h}$ denote the holdings of foreign household of the domestic asset, $\sigma$ the stochastic volatility of the dividend process, and $p$ the disaster probability. For each of these variables we first define a discrete grid. All policy functions are approximated at each $\sigma, x, p$ by

$$
f\left(\omega, S^{f, h}, \sigma, x, p\right)=\sum_{i=0}^{n_{w}} \sum_{j=0}^{n_{S} f, h} \phi_{i j p} \Psi_{i j}\left(w, S^{f, h}\right)
$$

where $\Psi_{i j}(k, b)=T_{i-1}\left(2((\omega-\underline{\omega}) /(\bar{\omega}-\underline{\omega})-1) T_{j-1}\left(2\left(\left(S^{f, h}-\underline{S^{f, h}}\right) /\left(\overline{S^{f, h}}-\underline{S^{f, h}}\right)-1\right), T_{l}(x)=\cos (l \arccos x)\right.\right.$, $l=0,1, \ldots, n_{x}$ and $x=\omega, S^{f, h}$ generate the Chebyshev polynomials of degree $n_{x}$. The higher the degree of the polynomial the more precise is the solution. Let $\underline{\omega}$ denote the lower bound for the share of wealth and $\bar{\omega}$ the upper bound. The bounds for $S^{f, h}$ follow the same notation. ${ }^{7}$ While other basis functions can be used Chebyshev polynomials have the useful feature of being orthogonal on $[-1,1]$ with respect to the inner product defined by the weighting function $\left(1-k^{2}\right)^{-1 / 2}$. This makes it feasible to keep the number of unknown coefficients low. The central idea of the collocation method is to pick (collocation) points for $\omega, S^{f, h}, \sigma, x, p$ for which a to be defined residual function $R\left(\left(\omega, S^{f, h}, \sigma, x, p, \phi\right)=0\right.$. Regarding the choice of the collocation points the Chebyshev Interpolation Theorem says, see Judd (1992), that the choice of the Chebyshev zeroes is optimal for rapid convergence with an increasing number of collocation points. The zeroes of a Chebyshev polynomial of order $\mathrm{N}$ can be found through

$$
x_{k}=\cos \left(\frac{(2 k+1) \pi}{2 N}\right) \quad \text { for } \quad k=0,1, \ldots, N-1
$$

The policy functions that to be approximated are $P\left(\omega, S^{f, h}, \sigma, x, p\right), P^{*}\left(\omega, S^{f, h}, \sigma, x, p\right)$,

$$
C\left(\omega, S^{f, h}, \sigma, x, p\right), C^{*}\left(\omega, S^{f, h}, \sigma, x, p\right), S^{h, h}\left(\omega, S^{f, h}, \sigma, x, p\right), S^{h, f}\left(\omega, S^{f, h}, \sigma, x, p\right), S^{f, h}\left(\omega, S^{f, h}, \sigma, x, p\right) \text { and }
$$
$S^{f, f}\left(\omega, S^{f, h}, \sigma, x, p\right)$. Each iteration consists of two key steps: First, given the guess for the policy functions and all possible combinations of states tomorrow we solve for the implied relative wealth tomorrow, $\omega^{\prime}$. Using the guess for the policy functions and $\omega^{\prime}$ we can then compute expectations and solve the for the coefficient $\phi$ that imply $R\left(\left(\omega, S^{f, h}, \sigma, x, p, \phi\right)=0\right.$. There is a trade of between precision of the solution

\footnotetext{
${ }^{7}$ Chebyshev polynomials can also be generated recursively, $T_{0}(k)=1, T_{1}(k)=k$, by $T_{n+1}(k)=2 k T_{n}(k)-T_{n-1}(k)$ for $n=2,3, \ldots \ldots$.
} 
and computational feasibility. While higher order polynomials allow for highly non-linear policy functions, they lead to a large number of unknown coefficients at the same time which makes the computation of the solution very difficult. In order to ease this problem we therefore start with a low order polynomial for the state variables $S^{f, h}\left(\omega, S^{f, h}, \sigma, x, p\right)$. A crucial element to reach convergence is the initial guess for the $\phi$ coefficients. It is helpful to use the solution of a the model without expropriation risk as initial guess for the model with expropriation risk. Updating of the guess via a Levenberg-Marquardt algorithm and iterating until convergence gives the solution to the model. The Jacobian for the Levenberg-Marquardt method is computed analytically which results in a significant computational speedup compared in comparison to computing it via finite differences. The result of the low order polynomial can be used to increase the order of the polynomials where the additional coefficients are assigned a zero initial guess.

Figure 4 reports the foreign and domestic consumption, the prices of the foreign and domestic trees, as well as the foreign and domestic shares of the two trees, all as a function of the share of the domestic tree held by foreign investors. 

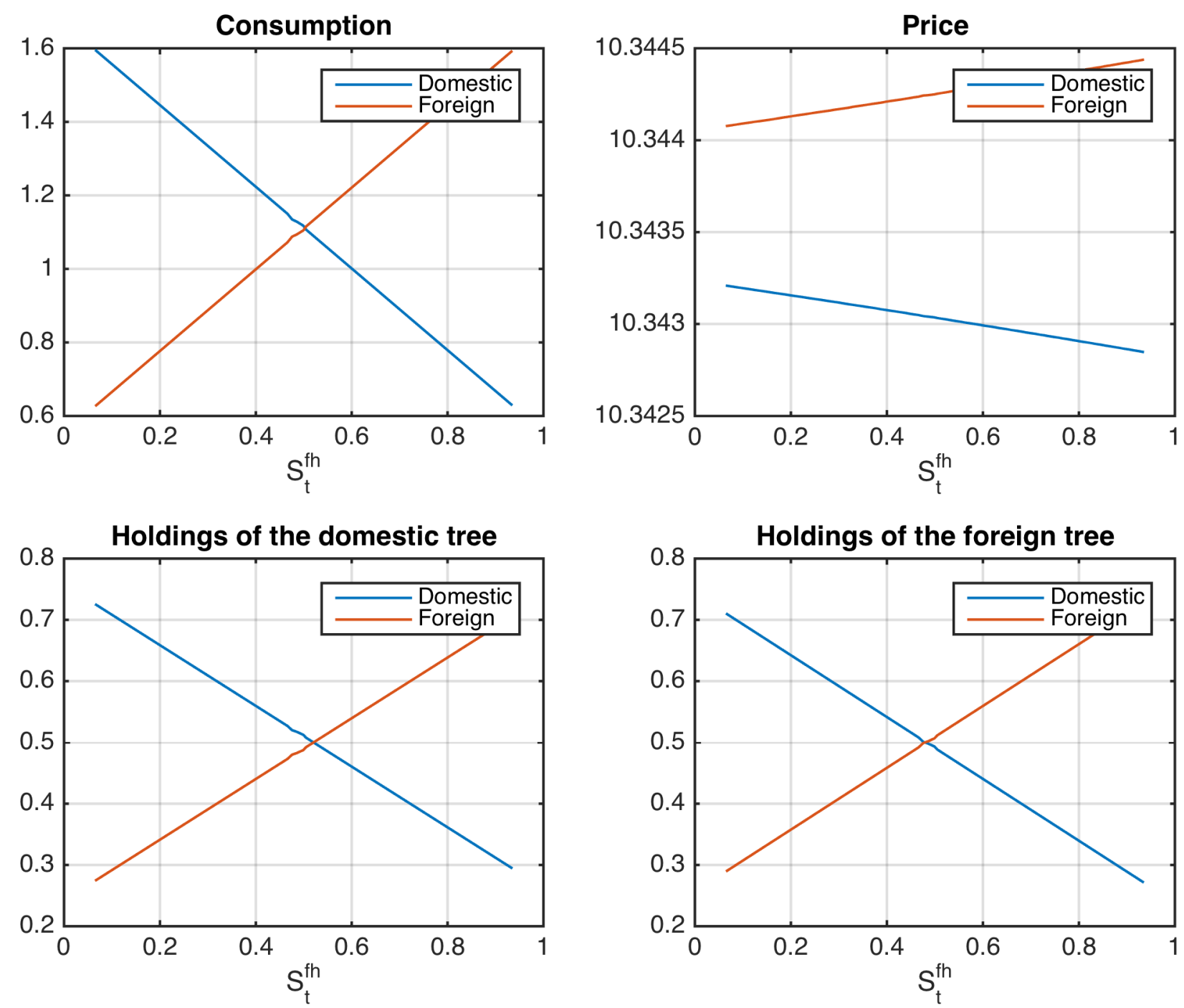

Figure 4: Model Equilibrium: Consumption, Price and Shares of the Trees as a Function of Foreigners' Holdings of the Domestic Tree — The model is simulated with the parameters described in Table 4. 